AGAINST THE ACADEMICS

$\longrightarrow$ 
This page intentionally left blank 


\title{
AGAINST
}

\section{THE ACADEMICS}

St. Augustine's

Cassiciacum Dialogues,

VOLUME 1

Translation, Annotation, and Commentary by

Michael P. Foley

\author{
Yale \\ UNIVERSITY \\ PRESS
}

New Haven \& London 
Published with assistance from the foundation established in memory of Philip Hamilton McMillan of the Class of 1894, Yale College.

Copyright (C) 2019 by Michael P. Foley.

All rights reserved.

This book may not be reproduced, in whole or in part, including illustrations, in any form (beyond that copying permitted by Sections 107 and 108 of the U.S. Copyright Law and except by reviewers for the public press), without written permission from the publishers.

Yale University Press books may be purchased in quantity for educational, business, or promotional use. For information, please e-mail sales.press@yale. edu (U.S. office) or sales@yaleup.co.uk (U.K. office).

Set in Electra type by IDS Infotech, Ltd. Printed in the United States of America.

Library of Congress Control Number: 2018961156

ISBN 978-0-300-23851-8 (hardcover : alk. paper)

ISBN 978-o-300-23855-6 (paper : alk. paper)

A catalogue record for this book is available from the British Library.

This paper meets the requirements of ANSI/NISO Z39.48-1992 (Permanence of Paper). 


\section{In grateful memory of}

Fathers Emest L. Fortin, A.A., and Matthew L. Lamb, inspiring teachers who sparked, fanned, and guided my love of these dialogues. 
Noverim me, noverim te.

May I know myself, may I know Thee.

-Soliloquies 2.1.1 